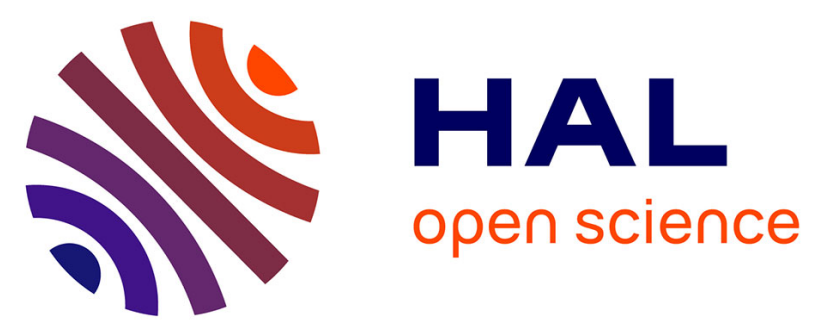

\title{
The changing scene of allogeneic stem cell transplantation for chronic myeloid leukemia-a report from the German Registry covering the period from 1998 to 2004
}

Ulrike Bacher, Evgeny Klyuchnikov, Tatjana Zabelina, Hellmut Ottinger, Dietrich W. Beelen, Hubert Schrezenmeier, Gerhard Ehninger, Carlheinz Müller, Jürgen Berger, Meinolf Suttorp, et al.

\section{- To cite this version:}

Ulrike Bacher, Evgeny Klyuchnikov, Tatjana Zabelina, Hellmut Ottinger, Dietrich W. Beelen, et al.. The changing scene of allogeneic stem cell transplantation for chronic myeloid leukemia-a report from the German Registry covering the period from 1998 to 2004. Annals of Hematology, 2009, 88 (12), pp.1237-1247. 10.1007/s00277-009-0737-3 . hal-00535050

\author{
HAL Id: hal-00535050 \\ https://hal.science/hal-00535050
}

Submitted on 11 Nov 2010

HAL is a multi-disciplinary open access archive for the deposit and dissemination of scientific research documents, whether they are published or not. The documents may come from teaching and research institutions in France or abroad, or from public or private research centers.
L'archive ouverte pluridisciplinaire HAL, est destinée au dépôt et à la diffusion de documents scientifiques de niveau recherche, publiés ou non, émanant des établissements d'enseignement et de recherche français ou étrangers, des laboratoires publics ou privés. 


\title{
The changing scene of allogeneic stem cell transplantation for chronic myeloid leukemia - a report from the German Registry covering the period from 1998 to 2004
}

\author{
Ulrike Bacher • Evgeny Klyuchnikov $\cdot$ Tatjana Zabelina $\cdot$ Hellmut Ottinger • \\ Dietrich W. Beelen • Hubert Schrezenmeier • Gerhard Ehninger • Carlheinz Müller • \\ Jürgen Berger • Meinolf Suttorp • Hans-Jochem Kolb • Nicolaus Kröger • \\ Axel R. Zander
}

Received: 1 October 2008 /Accepted: 11 March 2009 / Published online: 25 March 2009

(C) Springer-Verlag 2009

\begin{abstract}
Due to the recent changes in the indication to allogeneic stem cell transplantation (SCT) in chronic myeloid leukemia (CML), we retrospectively analyzed 1,716 patients with different CML stages who received an allograft from related $(n=767)$ or unrelated donors $(n=938)$ within the German Registry of Stem Cell Transplantation (DRST) from 1998 to 2004. Myeloablative conditioning was performed in $724 / 871$ cases (83\%), dose-reduced conditioning in 147/871 (17\%). Annual transplantations were decreasing from 357 to $98(28 \%)$ in the period of study, but the proportion of advanced cases was increasing from $32 \%(112 / 346)$ to $53 \%(50 / 94)$ of all SCTs. Stage of
\end{abstract}

Ulrike Bacher and Evgeny Klyuchnikov contributed equally to this manuscript.

U. Bacher $(\bowtie) \cdot$ E. Klyuchnikov $\cdot$ T. Zabelina $\cdot$ N. Kröger $\cdot$

A. R. Zander

Interdisziplinäre Klinik für Stammzelltransplantation,

Universitäres Cancer Center Hamburg (UCCH),

Martinistr. 52,

20246 Hamburg, Germany

e-mail: u.bacher@uke.de

E. Klyuchnikov

Klinik für Stammzelltransplantation,

State Pavlov's Medical University,

St. Petersburg, Russia

H. Ottinger · D. W. Beelen · H. Schrezenmeier $\cdot$ G. Ehninger $\cdot$

C. Müller

Deutsches Register für Stammzelltransplantation (DRST) c/o

KMT-Klinik, Universitätsklinikum Essen und Zentrales

Knochenmarkspender-Register in Deutschland (ZKRD),

Ulm, Germany

H. Schrezenmeier

Institut für Klinische Transfusionsmedizin und Immungenetik Ulm, Universität Ulm,

Ulm, Germany disease, intervals from diagnosis, and patients' age were independent prognostic parameters, while peripheral stem cells and unrelated transplantation seemed equal to bone marrow/related transplantation. This study demonstrates that allo-SCT still has an important role in advanced CML, which emphasizes the need for optimized transplantation strategies for these high-risk patients.

Keywords Allogeneic stem cell transplantation (SCT) Chronic myeloid leukemia (CML) - Dose-reduced conditioning (RIC) · Myeloablative conditioning · German Registry of Stem Cell Transplantation (DRST)

G. Ehninger

Medizinische Klinik und Poliklinik I,

Universitätsklinikum Carl Gustav Carus Dresden,

Dresden, Germany

J. Berger

Zentrum für Experimentelle Medizin, Institut für Medizinische

Biometrie und Epidemiologie, Universität Hamburg,

Hamburg, Germany

M. Suttorp

Klinik und Poliklinik für Kinder- und Jugendmedizin,

Carl Gustav Carus Universität Dresden,

Dresden, Germany

H.-J. Kolb

III. Medizinische Klinik,

Ludwig-Maximilians-Universität München,

Munich, Germany 


\section{Introduction}

Indication to allogeneic stem cell transplantation (SCT) in chronic myeloid leukemia (CML) has experienced significant changes in recent years. After the introduction of the tyrosine kinase inhibitor (TKI) imatinib (IM) with estimated survival rates close to $90 \%$ after 5 years [1] and progressionfree survival of $>97 \%$ once major molecular remission is achieved [2], the annual transplantation rates in CML are worldwide decreasing [3,4], especially since 2002, when IM was approved [5]. Treatment options are further broadened by second-generation TKIs such as nilotinib or dasatinib [6].

However, according to the recommendations of the European LeukemiaNet (ELN), allo-SCT should still be discussed in those patients who show failure of IM or suboptimal response [7]. Another first-line indication to allo-SCT is still represented by advanced disease such as accelerated (AP) or blast phase (BP). Due to the introduction of IM and of second-generation TKIs in the treatment before SCT [8, 9], more patients in advanced disease achieve remission before SCT [7, 10]. Therefore, allo-SCT took a shift towards advanced disease or cases with imatinib resistance [11, 12]. Reduced intensity conditioning (RIC) broadened transplantation strategies [13] and allowed the inclusion of patients with comorbidity, advanced disease, or higher age [14], who would have been excluded from SCT in former years.

With regard to the recent modifications of treatment strategies in CML, we here performed a retrospective multicenter analysis of all 1,716 adult and pediatric stem cell recipients with diverse stages of CML who had been registered within the German Registry of Stem Cell Transplantation (Deutsches Register für Stammzelltransplantation; DRST) in the period from 1998 to 2004. The aim of the study was to document changes of transplantation activity and of risk profiles of CML patients and to define outcomes and risk factors of current allo-SCT in these patients within the DRST.

\section{Patients and methods}

From January 1998 to December 2004, a total of 1,716 patients receiving an allograft from unrelated or related donors were registered within the DRST by 30 transplantation centers and were included in this retrospective analysis. The minimum essential data set was available for 1,526 patients. For 45 patients, the current vital status was unknown. The maximum number of patients for time to event analyses was 1,671 .

\section{Characteristics of patients and donors}

There were 1,014 males (59.1\%) and 701 females (40.9\%) (sex missing in one case). Median age of patients was 40 years (range 1-68 years). Considering the distribution of patients within the diverse age groups, only 66 patients $(4 \%)$ were $>59$ years of age, whereas the majority $(1,528 /$ 1,$716 ; 89 \%$ ) was between 20 and 59 years old. Thus, most patients were in the age groups $>40$ years $(53 \%)$ (Tables 1 and 2). The majority of patients in whom the stage of disease at SCT was available were in first chronic phase (1. CP) $(1,084 / 1,626 ; 67 \%)$ while $542(33 \%)$ were in more advanced disease. Transplantation was performed in 856 of 1,716 cases $(50 \%)$ within the first year from diagnosis. The

Table 1 Characteristics of all 1,716 patients and donors

\begin{tabular}{ll}
\hline Parameter & Number $(\%)$ \\
\hline Patient's age & \\
$<40$ years & $803 / 1,716(46.8)$ \\
$>40$ years & $913 / 1,716(53.2)$ \\
Sex & \\
Males & $1,014 / 1,715(59.1)$ \\
Females & $701 / 1,715(40.9)$ \\
Unknown & 1 \\
Interval from diagnosis to SCT & \\
$<1$ year to SCT & $860 / 1,716(50.1)$ \\
$>1$ year to SCT & $856 / 1,716(49.9)$ \\
Disease status at transplantation & \\
CP1 & $1,084 / 1,626(66.7)$ \\
CP2, CP3 & $203 / 1,626(12.4)$ \\
AP & $211 / 1,626(13.0)$ \\
BP & $128 / 1,626(7.9)$ \\
Unknown & 90 \\
Donor type & \\
Matched sibling & $1,069 / 1,709(62.6)$ \\
Matched related & $640 / 1,709(37.4)$ \\
Matched unrelated & 7 \\
Mismatched related & $616 / 1,705(36.1)$ \\
Mismatched unrelated & $67 / 1,705(3.9)$ \\
Unknown & $764 / 1,705(44.8)$ \\
Donor-patient sex matching & $90 / 1,705(5.3)$ \\
Fem. donor/male patient & $168 / 1,705(9.9)$ \\
All others & 11 \\
Unknown & \\
Stem cell source & $306 / 1,565(19.6 \%)$ \\
BnsC & $1,259 / 1,565(80.4 \%)$ \\
\hline
\end{tabular}


Table 2 Five years overall survival (OS) of patients with CML, univariate analysis

\begin{tabular}{|c|c|c|c|}
\hline \multirow[t]{2}{*}{ Parameter } & \multicolumn{3}{|l|}{ All patients } \\
\hline & Number & 5-year OS & $p$ \\
\hline \multicolumn{4}{|l|}{ Patients' sex } \\
\hline Male & $683 / 1,671$ & $55 \%(95 \% \mathrm{CI}=52-56)$ & \multirow[t]{2}{*}{0.05} \\
\hline Female & $988 / 1,671$ & $62 \%(95 \% \mathrm{CI}=58-66)$ & \\
\hline \multicolumn{4}{|l|}{ Patient's age } \\
\hline $1-19$ & $119 / 1,671$ & $47 \%(95 \% \mathrm{CI}=37-57)$ & \multirow[t]{4}{*}{$<0.001$} \\
\hline $20-39$ & $661 / 1,671$ & $67 \%(95 \% \mathrm{CI}=63-71)$ & \\
\hline $40-59$ & $829 / 1,671$ & $54 \%(95 \% \mathrm{CI}=50-58)$ & \\
\hline$>59$ & $62 / 1,671$ & $37 \%(95 \% \mathrm{CI}=17-57)$ & \\
\hline$<40$ years & $780 / 1,671$ & $64 \%(95 \% \mathrm{CI}=60-68)$ & \multirow[t]{2}{*}{$<0.001$} \\
\hline$\geq 40$ years & $891 / 1,671$ & $53 \%(95 \% \mathrm{CI}=49-57)$ & \\
\hline \multicolumn{4}{|l|}{ Status of remission } \\
\hline $\mathrm{CP} 1$ & $1,058 / 1,587$ & $70 \%(95 \% \mathrm{CI}=67-73)$ & \multirow[t]{3}{*}{$<0.001$} \\
\hline Others & $529 / 1,587$ & $34 \%(95 \%$ CI $=29-39)$ & \\
\hline Unknown & & 84 & \\
\hline \multicolumn{4}{|c|}{ Interval from diagnosis to $\mathrm{SCT}$} \\
\hline$\leq 1$ year & $838 / 1,671$ & $66 \%(95 \% \mathrm{CI}=62-70)$ & \multirow[t]{2}{*}{$<0.001$} \\
\hline$>1$ year & $833 / 1,671$ & $50 \%(95 \% \mathrm{CI}=46-54)$ & \\
\hline \multicolumn{4}{|l|}{ Type of donor } \\
\hline Unrelated & $914 / 1,662$ & $55 \%(95 \% \mathrm{CI}=51-59)$ & \multirow[t]{3}{*}{0.004} \\
\hline Related & $748 / 1,662$ & $61 \%(95 \% \mathrm{CI}=57-65)$ & \\
\hline Unknown & & 9 & \\
\hline \multicolumn{4}{|l|}{ Donor sex } \\
\hline Male & $917 / 1,526$ & $58 \%(95 \% \mathrm{CI}=54-62)$ & \multirow[t]{3}{*}{0.29} \\
\hline Female & $609 / 1,526$ & $55 \%(95 \% \mathrm{CI}=51-56)$ & \\
\hline Unknown & & 145 & \\
\hline \multicolumn{4}{|l|}{ Donor-patient sex matching } \\
\hline Fem. donor/male patient & $301 / 1,526$ & $49 \%(95 \% \mathrm{CI}=43-55)$ & \multirow[t]{3}{*}{0.004} \\
\hline All others & $1,225 / 1,526$ & $59 \%(95 \% \mathrm{CI}=56-62)$ & \\
\hline Unknown & & 145 & \\
\hline \multicolumn{4}{|l|}{ HLA compatibility } \\
\hline HLA match & $1,407 / 1,662$ & $60 \%(95 \% \mathrm{CI}=57-63)$ & \multirow[t]{3}{*}{$<0.001$} \\
\hline HLA mismatch & $255 / 1,662$ & $45 \%(95 \% \mathrm{CI}=38-52)$ & \\
\hline Unknown & & 9 & \\
\hline \multicolumn{4}{|l|}{ Source of stem cells } \\
\hline $\mathrm{BM}$ & $626 / 1,665$ & $64 \%(95 \% \mathrm{CI}=60-68)$ & \multirow[t]{3}{*}{0.004} \\
\hline PBSC & $1,039 / 1,665$ & $54 \%(95 \% \mathrm{CI}=50-58)$ & \\
\hline Unknown & & 6 & \\
\hline \multicolumn{4}{|l|}{ Conditioning } \\
\hline RIC & $147 / 871$ & $42 \%(95 \% \mathrm{CI}=33-51)$ & $<0.001$ \\
\hline Standard & $724 / 871$ & $62 \%(95 \% \mathrm{CI}=58-66)$ & \\
\hline Unknown & & 800 & \\
\hline TBI & & & \\
\hline With TBI & $823 / 1,646$ & $58 \%(95 \% \mathrm{CI}=54-62)$ & 0.076 \\
\hline Without TBI & $823 / 1,646$ & $56 \%(95 \% \mathrm{CI}=52-60)$ & \\
\hline Unknown & & 25 & \\
\hline Gratwohl score & & & \\
\hline $0-1$ & $142 / 1,162$ & $71 \%(95 \% \mathrm{CI}=62-80)$ & $<0.001$ \\
\hline 2 & $246 / 1,162$ & $78 \%(95 \% \mathrm{CI}=72-84)$ & \\
\hline
\end{tabular}


Table 2 (continued)

\begin{tabular}{lll}
\hline Parameter & All patients & \\
\cline { 2 - 3 } & Number & 5 -year OS \\
\hline 3 & $312 / 1,162$ & $64 \%(95 \%$ CI $=58-70)$ \\
4 & $242 / 1,162$ & $48 \%(95 \%$ CI $=40-56)$ \\
$5-7$ & $220 / 1,162$ & $32 \%(95 \%$ CI $=25-39)$ \\
Unknown & & 186 \\
Year of SCT & & \\
$1998(2-3-5$ years $)$ & $356 / 1,671$ & $62-60-58 \%(95 \%$ CI $=57-67 ; 55-65 ; 53-64)$ \\
$1999(2-3-5$ years $)$ & $367 / 1,671$ & $59-54-52 \%(95 \%$ CI $=54-65 ; 48-60 ; 46-58)$ \\
$2000(2-3-5$ years $)$ & $253 / 1,671$ & $63-61-61 \%(95 \%$ CI $=57-69 ; 55-67 ; 55-67)$ \\
$2001(2-3-5$ years $)$ & $239 / 1,671$ & $63-60-57 \%(95 \%$ CI $=57-70 ; 53-67 ; 49-65)$ \\
$2002(2-3$ years $)$ & $236 / 1,671$ & $62-60 \%(95 \%$ CI $=55-69 ; 68-53)$ \\
$2003(2$ years $)$ & $126 / 1,671$ & $64 \%(95 \%$ CI $=54-74)$ \\
$2004(1$ year $)$ & $94 / 1,671$ & $76 \%(95 \%$ CI $=65-87)$ \\
\hline
\end{tabular}

$O S$ overall survival; $C P 1$ first chronic phase; $A P$ accelerated phase; $B P$ blast phase; $S C T$ allogeneic stem cell transplantation; $B M$ bone marrow; $P B S C$ peripheral blood stem cells; RIC reduced intensity conditioning; TBI total body irradiation

majority of SCTs was performed from unrelated donors (932/1,705 patients; 55\%); 773/1,705 recipients had a related donor (45\%), of these in eight cases a twin. HLAmatched donors were available for 1,447/1,705 stem cell recipients $(85 \%)$. The majority of SCTs was sex matched $(936 / 1,565 ; 60 \%)$. Donors were female in $624 / 1,566$ cases $(40 \%)$ and male in $942 / 1,566$ cases $(60 \%)$ where data were available. Peripheral blood stem cells (PBSC) $(1,069 / 1,709$; $63 \%$ ) were more frequently used as stem cell source than bone marrow (BM) $(640 / 1,709 ; 37 \%)$. No patient received cord blood.

Conditioning was performed by dose-reduced strategies (RIC) in 156/903 patients (17\%) and by standard conditioning (SIC) in 747/903 patients (83\%) (conditioning strategies were available only in part of registered patients). Total body irradiation (TBI) was included in the conditioning regimens in $842 / 1,688$ patients $(50 \%)$.

Standard conditioning was either based on busulfan (cumulative dosage $12 \mathrm{mg} / \mathrm{m}^{2}$ ) combined with cyclophosphamide (cum. $120 \mathrm{mg} / \mathrm{m}^{2}$ ) or on TBI-based protocols (cum. 12 Gy) in combination with cyclophosphamide (cum. $120 \mathrm{mg} / \mathrm{m}^{2}$ ). Reduced conditioning was performed with busulfan (cum. $6.4-8 \mathrm{mg} / \mathrm{kg}$ ) in combination with fludarabine (cum. 150-180 mg/m²), or was performed according to Slavin et al. [15] or McSweeney et al. [16]. All protocols with cumulative busulfan dosages $<12 \mathrm{mg} / \mathrm{kg}$ were defined to be dose reduced.

Thus, the majority of patients of the present study were males $>40$ years, in first chronic phase, and received PBSCT from matched unrelated donors within the first year from diagnosis of CML.
According to the first German consensus meeting on immunogenetic donor search (1997), in the related setting, serological HLA-A, HLA-B, and low-resolution molecular genetic HLA-DRB1 typing was compulsory, and donor selection had to be based on the typing results for these HLA loci (two -A, two -B, two -DRB1). In the unrelated setting, HLA-A, -B, -DRB1, and -DQB1 was compulsory with HLA-A and -B being done with serological methods, and -DRB1 and -DQB at high resolution. Donors should be selected according to HLA-A, -B, and -DRB1 results (six HLA loci). If more than one HLA-A, -B, and -DRB1 identical donor was identified, donors also matched for -DQB1 should be preferred [17]. According to the second consensus (1999), matched donors were required to have the same HLA-A, -B, -DRB1, and -DQB1 antigens [18].

\section{Statistical analysis}

As this study was an exploratory analysis, no sample size calculation was performed. Endpoints were overall survival (OS), event-free survival (EFS), transplant-related mortality (TRM), incidence of relapse, and incidence and severity of acute GvHD. Characteristics of patients were expressed as median and range for continuous variables and frequencies for categorical variables. Categorical data were compared by the $\chi^{2}$ test or Fisher's exact test. Survival curves were estimated by the Kaplan-Meier method. The log-rank test was used to compare survival curves. The cumulative incidence method was used to estimate the incidence of TRM and relapse to account for competing event. 
In a first step, the following factors were included in univariate analyses: patient's age, patient's sex, sex mismatch vs. match, donor type, time from diagnosis to SCT, disease status at SCT, stem cell source (bone marrow vs. PBSC), conditioning with vs. without TBI, standard vs. reduced intensity conditioning, and year of SCT. Additionally, patients' outcome was correlated with the Gratwohl (EBMT) score based on the variables donor type, disease stage, age, sex status, and time from diagnosis to SCT (only patients with related SCT or matched unrelated SCT were included in this correlation) [19].

In a second step, all variables with a $p$ value $\leq 0.05$ were entered in a multivariable Cox regression model (forward elimination) to determine independent predictors. From this analysis, variables for conditioning were excluded, as the amount of patients with known data was noticeably low. For reason of shortness, only the results of the final models are presented as relative risks (hazard ratios) with respect to a reference category $(\mathrm{HR}=1)$ together with the $95 \%$ confidence interval (CI) and $p$ values.

Calculations were performed with SPSS, version 12 (SPSS Inc., 444 North Michigan Avenue, Chicago, IL 60611, USA). The competing risk analyses were done with ACCorD (V. Gebski, NHMRC Clinical Trials Centre, University of Sydney).

In spite of multiple testing, no adjustment of type I error was done. Therefore, results should be treated with caution.
Fig. 1 Probability of a overall survival (OS) and b event-free survival (EFS) for patients with CML, transplanted in the period 1998-2004

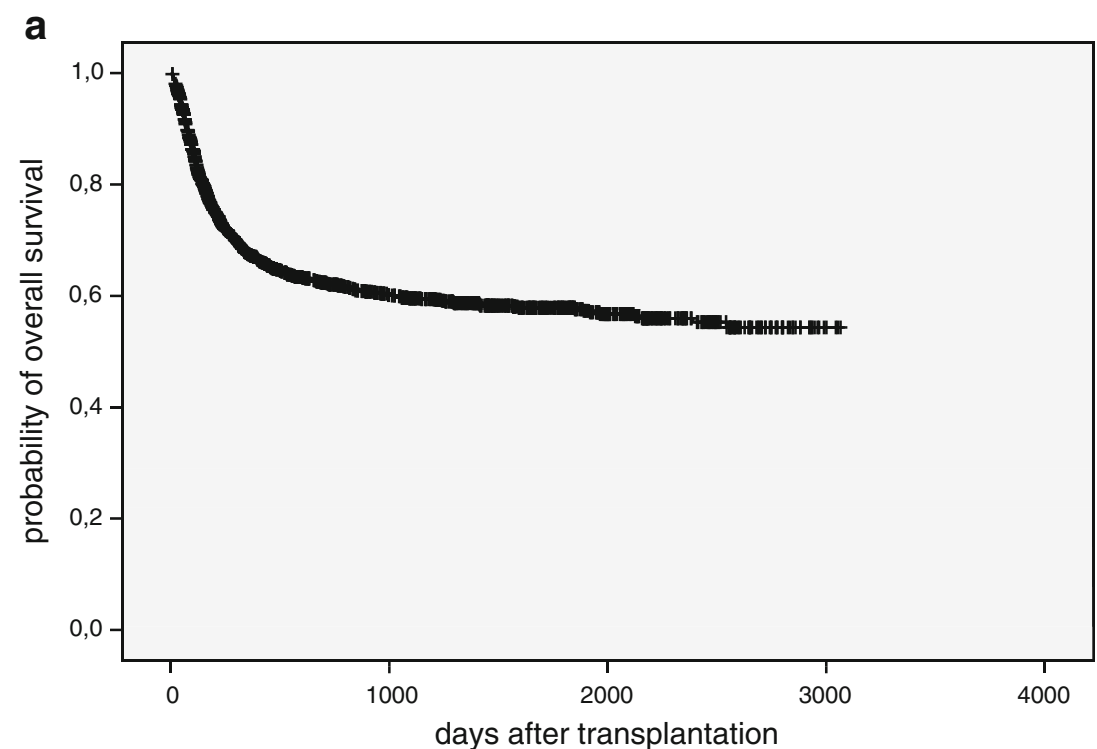

b

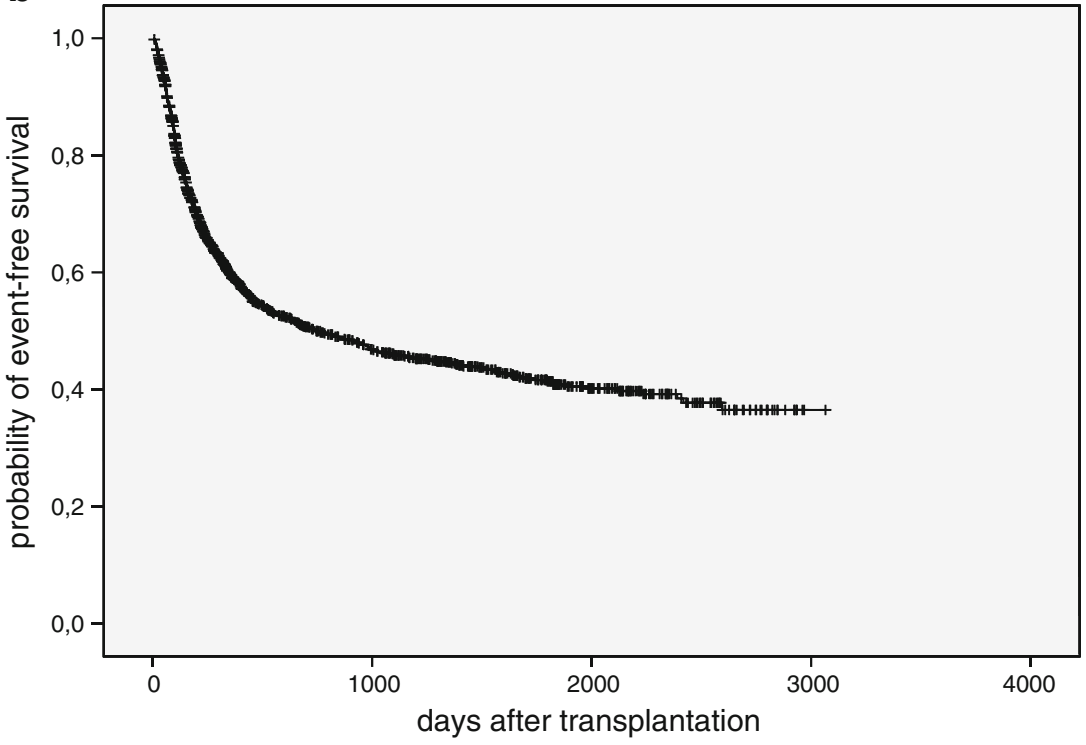




\section{Results}

Development between 1998 and 2004

Between 1998 and 2004, the annual SCT rate was decreasing from 357 to 98 , which corresponded to $28 \%$ of initial transplantations. This reduction was predominantly due to the decrease of annual transplantations in first chronic phase from 223 in 1998 to 45 SCTs in 2004 (20\%). In contrast, the reduction of SCTs in advanced stages $(>1$. CP, AP, BP) was less significant with a decrease from 112
(1998) to 50 SCTs (2004) and consequently to $45 \%$ of the initial transplantation rate only.

Thus, the proportion of SCTs in advanced stages was increasing from $112 / 346(32 \%)$ to $50 / 94(53 \%)$ in the 6year period of study.

Outcome and complications

Data of leukocyte engraftment $\left(>1 \times 10^{9} / 1\right)$ were available in 1,426 cases. Median leukocyte engraftment was reported on day +15 after SCT (range 8-69 days). Acute graft-versus-
Fig. 2 Cumulative incidence of a TRM and $\mathbf{b}$ relapse for patients with CML, transplanted in the period 1998-2004 a

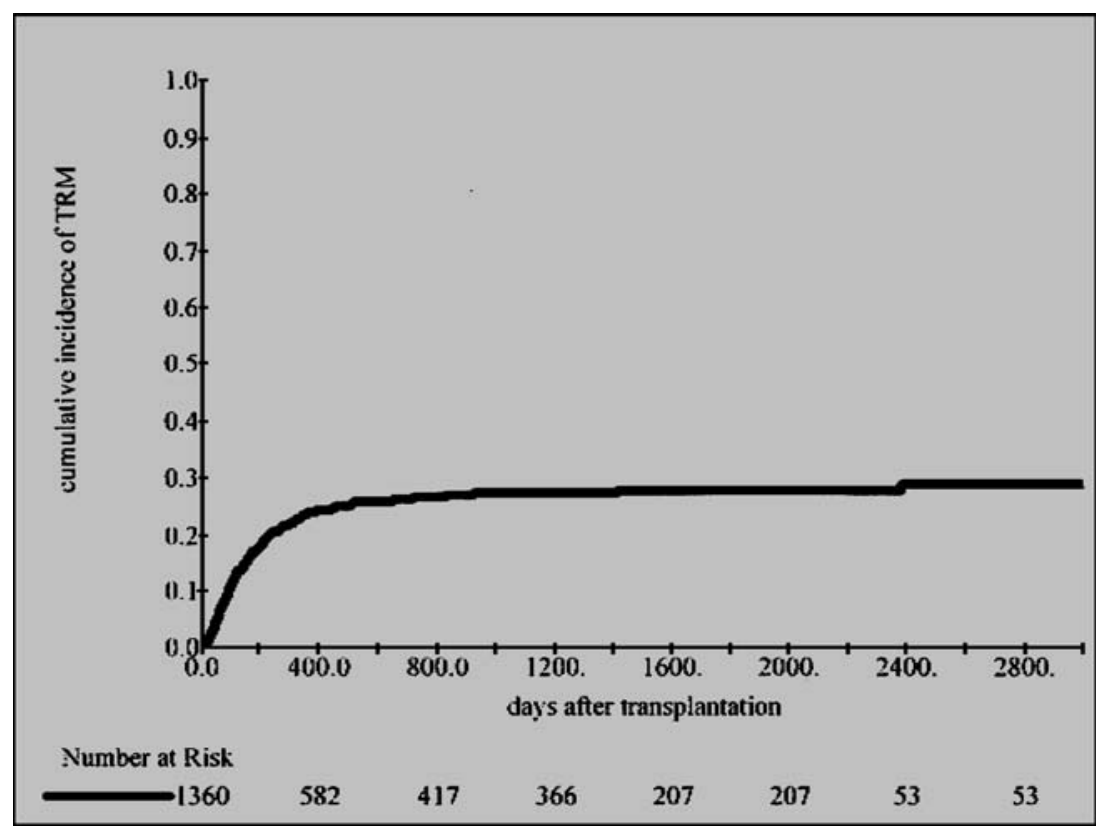

b

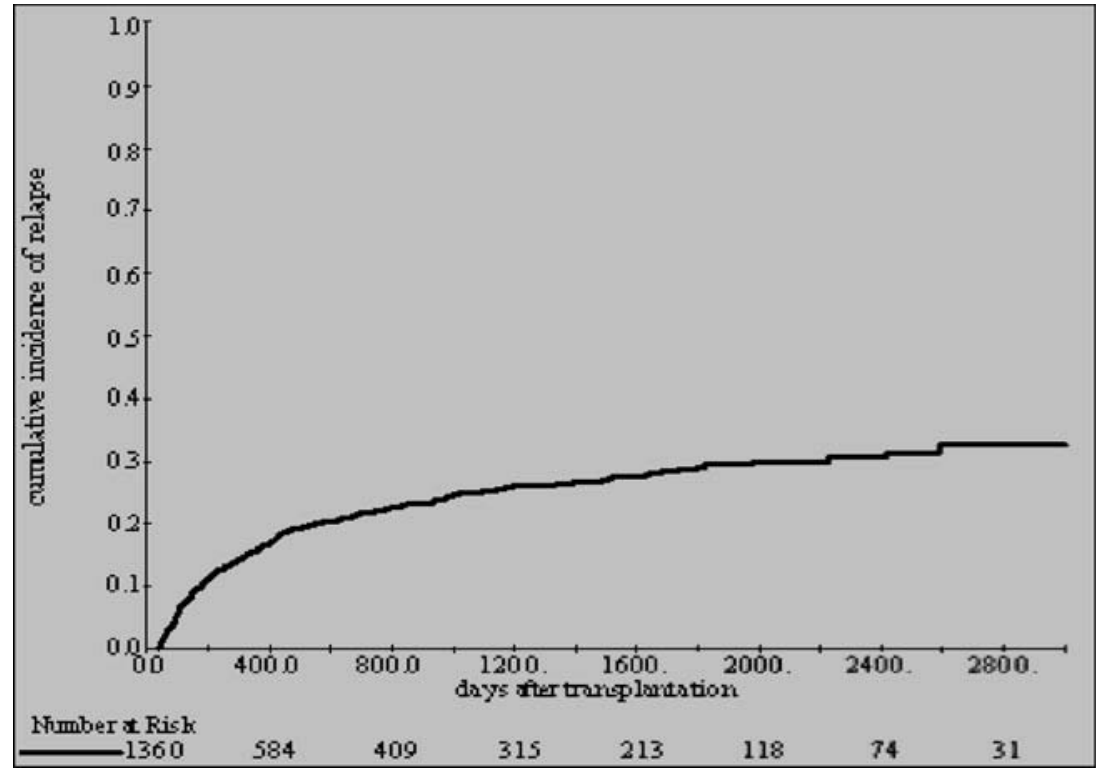


host disease (GvHD) grade II-IV was seen in 555/1,428 $(39 \%)$ of stem cell recipients (grade $\mathrm{II}=20 \%$, grade $\mathrm{III}=$ $11 \%$, grade IV $=8 \%$ ).

After a follow-up period of 5 years, 605 of 1,671 patients with available results had died, so 5 -year OS was $58 \%(95 \%$ CI $=55-61 \%$ ) (Fig. 1a). As 705/1,379 were alive without relapse, the 5 -year EFS was $41 \%(95 \% \mathrm{CI}=$ 38-44\%) (Fig. 1b).

Of a total of 1,360 patients, 339 died from transplantationrelated causes. The cumulative TRM incidence for 100 days, 1 year, and 5 years after SCT was $11 \%(95 \% \mathrm{CI}=9-13 \%)$, $24 \%(95 \% \mathrm{CI}=22-26 \%)$, and $28 \%(95 \% \mathrm{CI}=25-31 \%)$, respectively (Fig. 2a).

Relapse was documented in $340 / 1,380$ of patients $(25 \%)$. The 5 -year cumulative incidence of relapse was $29 \%(95 \% \mathrm{CI}=26-32 \%)$ (Fig. 2b). The median follow-up of living patients was 27 months, with a range from 2 weeks to 102 months.

\section{Parameters influencing prognosis}

For the definition of parameters influencing OS, univariate and multivariate analyses were performed.

According to univariate analysis, female sex, female donor/male recipient, patients' age $<40$ years, 1 . CP at transplantation, and the performance of transplantation with bone marrow as stem cell source from an HLA-matched related donor within the first year after diagnosis in standard conditioned patients were significantly associated with higher 5-year OS rates in statistical analyses $(p \leq$ 0.05). Higher risk groups according to the Gratwohl
(EBMT) score $(0-1,2,3,4$, and 5-7) were significantly correlated with worse OS $(p<0.001)$ (Table 2$)$.

In multivariate analysis, OS was improved for the following parameters: younger age, SCT in 1. CP, HLA-matched $\mathrm{SCT}$, and SCT in the first year from diagnosis $(p \leq 0.001)$. Patients' sex, stem cell source (BM/PBSC), and donor types (related/unrelated) did not improve the model fit (Table 3).

Comparison of patients with standard and reduced intensity conditioning

Comparison of the conditioning regimens showed improved 5-year OS for patients who received standard conditioning $(62 \% ; 95 \% \mathrm{CI}=58-66 \%)$ when compared to the cohort receiving reduced conditioning (RIC) (42\%; $95 \% \mathrm{CI}=33-51 \%)(p<0.001)$.

This result had to be seen in association to significant differences in the risk profiles of standard and reduced conditioned patients (Table 4): patients with RIC were more frequently in advanced disease $(>1 . \mathrm{CP})$, had a longer history of disease, and received SCT more frequently $>1$ year from diagnosis. Also, a significant higher proportion of RIC patients was $>40$ years of age $(p \leq 0.001)$. Median leukocyte engraftment was independent from the type of conditioning (day +15 in both groups). Severe GvHD (grade II-IV) (36\% vs. $37 \%)$ did not differ significantly between reduced and standard conditioned patients.

In contrast, HLA matching, stem cell source (BM/ PBSC), donor types (related/unrelated), or TBI within the conditioning regimen showed no significant differences between the RIC and SIC cohorts.
Fig. 3 Probability of overall survival (OS) for patients with CML according to the Gratwohl (EBMT) risk score

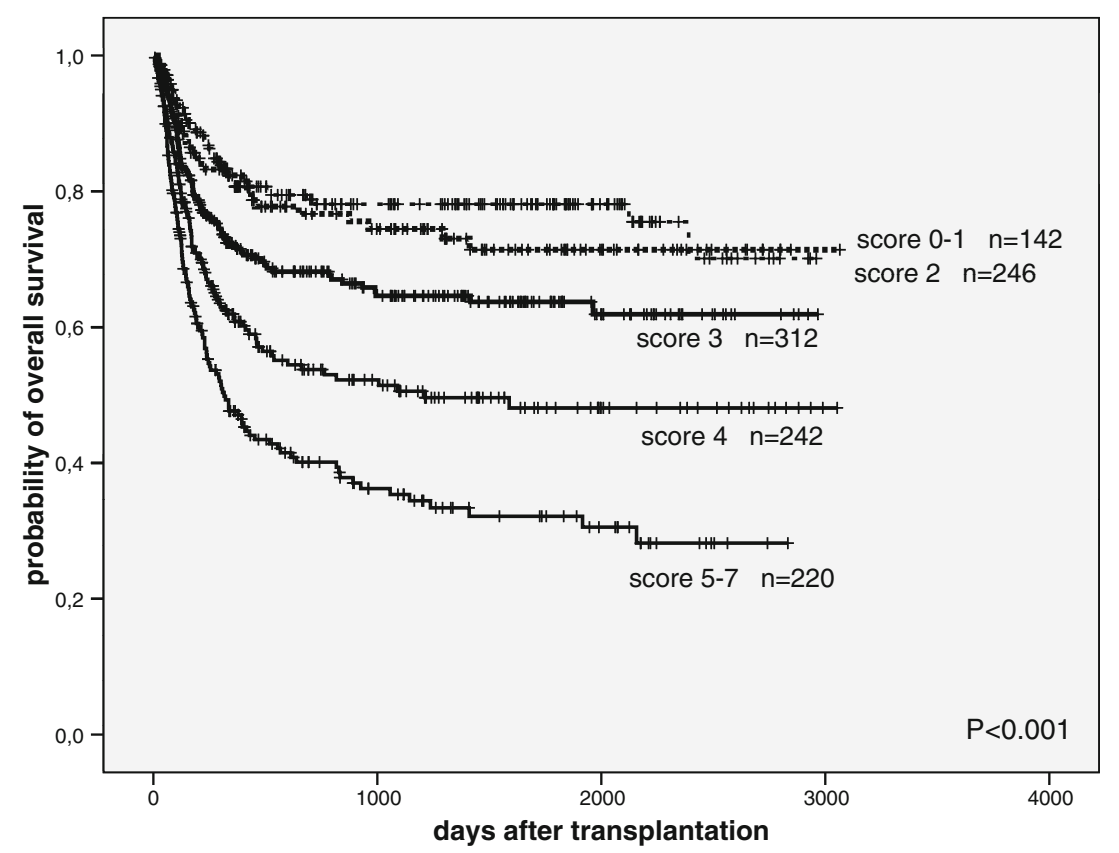


Table 3 Overall survival (OS) of patients with CML, multivariate analysis

CP1 1 chronic phase; SCT allogeneic stem cell transplantation; CI confidence interval

\begin{tabular}{|c|c|c|c|c|}
\hline Parameter & Number of patients & Relative risk & $95 \% \mathrm{CI}$ & $p$ \\
\hline \multicolumn{5}{|l|}{ Age } \\
\hline Continuous & 1,443 & 1.010 & $1.002-1.017$ & 0.011 \\
\hline \multicolumn{5}{|l|}{ Remissions status } \\
\hline $\mathrm{CP} 1$ & 945 & 1 & & \multirow[t]{2}{*}{$<0.001$} \\
\hline Others & 498 & 2.361 & $1.984-2.809$ & \\
\hline \multicolumn{5}{|c|}{ Interval from diagnosis } \\
\hline$\leq 1$ year & 709 & 1 & & \multirow[t]{2}{*}{$<0.001$} \\
\hline$>1$ year & 734 & 1.386 & $1.161-1.655$ & \\
\hline \multicolumn{5}{|l|}{ HLA matching } \\
\hline HLA match & 1,216 & 1 & & \multirow[t]{2}{*}{$<0.001$} \\
\hline HLA mismatch & 227 & 1.511 & $1.223-1.867$ & \\
\hline
\end{tabular}

\section{Discussion}

Due to the introduction of tyrosine kinase inhibitors, alloSCT has been shifted to a second-line strategy for high-risk patients and those who failed therapy with IM. This change of treatment strategy provides the background for this retrospective overview on current transplantation activities and strategies within the German Registry of Stem Cell Transplantation (DRST) in 1,716 adult and pediatric patients being registered between 1998 and 2004.

First, within this period, annual transplantations showed a decrease from 357 to 98 , which meant a reduction to
28\%. This was comparable to an EBMT study which documented a decrease from $\sim 1,400$ to $\sim 800$ annual SCTs for CML in chronic phase in the period 1999-2003 [3], and a CIBMTR study showed a reduction from 617 annual SCTs in 1998 to 223 in 2003 [4, 20]. Likewise, to the results of previous analyses, the reduction of annual SCTs was most significant in first chronic phase to $20 \%$ of the initial transplantation rate, whereas the decrease in advanced phases was less significant $(45 \%$ of the initial transplantation rate). Thus, the proportion of advanced phases showed an increase from $32 \%$ to $53 \%$ in this period. The CIBMTR documented as well an increase of SCTs for
Table 4 Comparison of frequencies between patients with standard (SIC; maximal number 747) and reduced intensity conditioning (RIC; maximal number 156)

\begin{tabular}{|c|c|c|c|c|c|c|}
\hline & & \multicolumn{2}{|l|}{ SIC } & \multicolumn{2}{|l|}{ RIC } & \multirow[t]{2}{*}{$p$} \\
\hline & & Number & $\%$ & Number & $\%$ & \\
\hline \multirow[t]{3}{*}{ Disease status } & 1. $\mathrm{CP}$ & $509 / 733$ & $69 \%$ & $69 / 151$ & $46 \%$ & \multirow[t]{3}{*}{$<0.001$} \\
\hline & Others & $224 / 733$ & $31 \%$ & $82 / 151$ & $54 \%$ & \\
\hline & Unknown & 14 & - & 5 & - & \\
\hline \multirow[t]{3}{*}{ HLA matching } & Match & $629 / 746$ & $84 \%$ & $139 / 156$ & $89 \%$ & \multirow[t]{3}{*}{0.14} \\
\hline & Mismatch & $117 / 746$ & $16 \%$ & $17 / 156$ & $11 \%$ & \\
\hline & Unknown & 1 & - & - & - & \\
\hline \multirow[t]{3}{*}{ Stem cell source } & $\mathrm{BM}$ & $269 / 745$ & $36 \%$ & $50 / 155$ & $32 \%$ & \multirow[t]{3}{*}{0.41} \\
\hline & PBSC & $476 / 745$ & $64 \%$ & $105 / 155$ & $68 \%$ & \\
\hline & Unknown & 2 & - & 1 & - & \\
\hline \multirow[t]{3}{*}{ Donor type } & Unrelated & $412 / 746$ & $55 \%$ & $89 / 156$ & $57 \%$ & \multirow[t]{3}{*}{0.72} \\
\hline & Related & $334 / 746$ & $45 \%$ & $67 / 156$ & $43 \%$ & \\
\hline & Unknown & 1 & - & - & - & \\
\hline \multirow[t]{4}{*}{ Patient's age } & $1-19$ years & $58 / 747$ & $8 \%$ & $3 / 156$ & $2 \%$ & \multirow[t]{4}{*}{$<0.001$} \\
\hline & $20-39$ years & $320 / 747$ & $43 \%$ & $29 / 156$ & $19 \%$ & \\
\hline & $40-59$ years & $359 / 747$ & $48 \%$ & $94 / 156$ & $60 \%$ & \\
\hline & $>59$ years & $10 / 747$ & $1 \%$ & $30 / 156$ & $19 \%$ & \\
\hline \multirow[t]{3}{*}{ TBI in conditioning } & Without TBI & $452 / 745$ & $61 \%$ & $85 / 156$ & $55 \%$ & \multirow[t]{3}{*}{0.25} \\
\hline & With TBI & $293 / 745$ & $39 \%$ & $71 / 156$ & $46 \%$ & \\
\hline & Unknown & 2 & - & - & & \\
\hline \multirow[t]{2}{*}{ Interval from diagnosis } & $\leq 1 \quad$ year & $407 / 747$ & $55 \%$ & $49 / 156$ & $31 \%$ & \multirow[t]{2}{*}{$<0.001$} \\
\hline & $>1$ year & $340 / 747$ & $45 \%$ & $107 / 156$ & $69 \%$ & \\
\hline
\end{tabular}


patients in 2. CP and AP from $24 \%$ to $41 \%$ [4], and the above EBMT study showed a greater decrease for allo-SCT in first chronic phase than in advanced disease [3]. These results suggest that allo-SCT still remains an important salvage option for patients in advanced CML.

Another focus were current strategies concerning donor types and stem cell sources. PBSC were already more frequently used than BM ( $38 \%$ vs. $62 \%$ of all SCTs), while the stem cell source (BM/PBSC) had no significant influence on survival in multivariate analyses. These data correspond to a retrospective study of Remberger et al., where PBSC and bone marrow from unrelated donors were associated with similar rates of GvHD, relapse, and survival [21]. In contrast, Elmaagacli et al. found improved overall survival with PBSC as stem cell source (94\% vs. $66 \%$ ) due to a significantly improved immune reconstitution for PBSCT and a lower TRM consequently to infections and severe aGvHD [22]. Others suggested that the influence of stem cell source might depend on the phase of disease and the interval between diagnosis and SCT.

A CIBMTR study had shown that while in patients with CML in 1. CP the risk of treatment failure was similar with PBSC or BM with adjusted 1-year probabilities of DFS of $63 \%$ and $74 \%$, respectively, there was an advantage for patients in advanced phases with adjusted 1-year probabilities of DFS of $68 \%$ with PBSC and $23 \%$ with BM. Causes of death after blood stem cell and bone marrow transplantation were similar [23]. These controversial results might reflect different conditioning strategies and selection criteria within the diverse studies. Thus, efforts to determine whether subsets of CML patients might benefit from either stem cell source should continue.

Further, in this analysis, SCT in CML was more frequently performed from unrelated than from related donors $(55 \%$ vs. $45 \%)$, without any influence on survival in accordance to previous reports [13, 14, 24]. However, others suggested worsening of prognosis by unrelated SCT in subgroups of patients: An NMDP study described for those CML patients in chronic phase undergoing early transplantation in the first year from diagnosis a similar or only slightly inferior 5-year DFS after matched unrelated vs. matched sibling transplantation, while there was a substantially worse 5-year DFS after matched URD in case of delayed SCT. Thus, 5-year DFS was 39\% for unrelated vs. $63 \%$ for related SCT in CP of CML when the delay was 1-2 years due to a significantly increased risk of graft failure and acute GvHD [25]. Mechanisms as immune compromise due to replacement of normal dendritic cells or natural killer cells with $B C R-A B L-$ positive effectors were suggested as possible explanations. Therefore, it should be further evaluated whether distinct subgroups of CML patients still might have a benefit from related SCT.
We then focused on the actual position of reduced conditioning in CML. Reduced conditioning strategies were documented in $17 \%$ of SCTs in this study, so it was obvious that RIC has found entrance in the transplantation schedules in CML. The proportion of RIC was rather constant between $11 \%$ and $23 \%$ of all transplantations within the 6-year period of the study. In contrast, EBMT data had shown an increase of reduced conditioning strategies from $1 \%$ to $31 \%$ from 1998 to 2003 [20], which probably can be explained by the later introduction of reduced conditioning in some European countries when compared to the centers contributing to the DRST.

There first seemed to be a survival advantage for the standard conditioned patients when compared to reduced conditioning (5-year OS of $62 \%$ vs. $42 \% ; p<0.001$ ). However, the risk profiles of the RIC patients were less favorable according to age, phase of disease, and intervals from diagnosis of CML to SCT, which has to be considered. Relapse rates did not differ significantly between RIC and SIC patients (17\% vs. $27 \%$ ) in this study when all CML stages were considered. This might be diverse when advanced disease is taken into account: a Czech study including 295 patients with advanced CML found a $45 \%$ relapse rate in reduced conditioned patients when compared to standard conditioning, where no relapse occurred [26]. Also, the frequency of severe aGvHD (grade II-IV) was equal in reduced and standard conditioned patients $(37 \%$ vs. $36 \%)$ in this DRST analysis. However, previous reports of similar frequencies of severe GvHD (grade II-IV) of $14 \%-19 \%$ irrespective of the intensity of conditioning [27] are in contrast to other studies where severe GvHD (grade II-IV) was significantly less frequent after reduced conditioning [28].

Thus, at this time, the optimal transplantation strategy for advanced CML cannot be precisely defined, but dosereduced strategies should be further explored for these complex cases. Also, the application of tyrosine kinase inhibitors (TKIs) of the first [29-32] or second generation [33] as preemptive strategy in the post-transplant period deserves further attention.

In conclusion, this overview gives further confirmation that, despite being removed from first-line strategies since the introduction of imatinib, allo-SCT still plays an important role in higher advanced CML [34]. In addition, survival seems to be significantly influenced by the phase of disease at diagnosis, intervals between diagnosis and SCT, patients' age, and the Gratwohl (EBMT) risk score, while peripheral blood stem cells and unrelated transplantation are already predominant in CML with an equal outcome when compared to bone marrow as stem cell source or related transplantation. Finally, reduced conditioning has found its place in allo-SCT in CML and will probably be further developed in the future, which might 
contribute to the needs of the high-risk patients now being in the focus of allo-SCT in CML.

Acknowledgements The authors would like to thank Karin Fuchs (DRST office), Sandra Allgaier, Anja Müller (DRST database), and all local DRST data managers for their continuous support.

\section{References}

1. Druker BJ, Guilhot F, O'Brien SG, Gathmann I, Kantarjian H, Gattermann N, Deininger MW, Silver RT, Goldman JM, Stone RM, Cervantes F, Hochhaus A, Powell BL, Gabrilove JL, Rousselot P, Reiffers J, Cornelissen JJ, Hughes T, Agis H, Fischer T, Verhoef G, Shepherd J, Saglio G, Gratwohl A, Nielsen JL, Radich JP, Simonsson B, Taylor K, Baccarani M, So C, Letvak L, Larson RA (2006) Five-year follow-up of patients receiving imatinib for chronic myeloid leukemia. N Engl J Med 355:2408-2417. doi:10.1056/NEJMoa062867

2. Mauro MJ, Deininger MW (2006) Chronic myeloid leukemia in 2006: a perspective. Haematologica 91:152

3. Gratwohl A, Baldomero H, Frauendorfer K, Urbano-Ispizua A, Niederwieser D (2007) Results of the EBMT activity survey 2005 on haematopoietic stem cell transplantation: focus on increasing use of unrelated donors. Bone Marrow Transplant 39:71-87. doi:10.1038/sj.bmt. 1705555

4. Giralt SA, Arora M, Goldman JM, Lee SJ, Maziarz RT, McCarthy PL, Sobocinski KA, Horowitz MM (2007) Impact of imatinib therapy on the use of allogeneic haematopoietic progenitor cell transplantation for the treatment of chronic myeloid leukaemia. $\mathrm{Br}$ J Haematol 137:461-467. doi:10.1111/j.1365-2141.2007.06582.x

5. Ren R (2005) Mechanisms of BCR-ABL in the pathogenesis of chronic myelogenous leukaemia. Nat Rev Cancer 5:172-183. doi:10.1038/nrc1567

6. Kantarjian HM, Cortes J, Guilhot F, Hochhaus A, Baccarani M, Lokey L (2007) Diagnosis and management of chronic myeloid leukemia: a survey of American and European practice patterns. Cancer 109:1365-1375. doi:10.1002/cncr.22523

7. Baccarani M, Saglio G, Goldman J, Hochhaus A, Simonsson B, Appelbaum F, Apperley J, Cervantes F, Cortes J, Deininger M, Gratwohl A, Guilhot F, Horowitz M, Hughes T, Kantarjian H, Larson R, Niederwieser D, Silver R, Hehlmann R (2006) Evolving concepts in the management of chronic myeloid leukemia: recommendations from an expert panel on behalf of the European LeukemiaNet. Blood 108:1809-1820. doi:10.1182/ blood-2006-02-005686

8. Cortes J, Rousselot P, Kim DW, Ritchie E, Hamerschlak N, Coutre S, Hochhaus A, Guilhot F, Saglio G, Apperley J, Ottmann O, Shah N, Erben P, Branford S, Agarwal P, Gollerkeri A, Baccarani M (2007) Dasatinib induces complete hematologic and cytogenetic responses in patients with imatinib-resistant or -intolerant chronic myeloid leukemia in blast crisis. Blood 109:3207-3213. doi:10.1182/blood-2006-09-046888

9. Kantarjian HM, Giles F, Gattermann N, Bhalla K, Alimena G, Palandri F, Ossenkoppele GJ, Nicolini FE, O’Brien SG, Litzow M, Bhatia R, Cervantes F, Haque A, Shou Y, Resta DJ, Weitzman A, Hochhaus A, le Coutre P (2007) Nilotinib (formerly AMN107), a highly selective BCR-ABL tyrosine kinase inhibitor, is effective in patients with Philadelphia chromosome-positive chronic myelogenous leukemia in chronic phase following imatinib resistance and intolerance. Blood 110:3540-3546. doi:10.1182/blood-2007-03-080689

10. Bornhauser M, Kroger N, Schwerdtfeger R, Schafer-Eckart K, Sayer HG, Scheid C, Stelljes M, Kienast J, Mundhenk P,
Fruehauf S, Kiehl MG, Wandt H, Theuser C, Ehninger G, Zander AR (2006) Allogeneic haematopoietic cell transplantation for chronic myelogenous leukaemia in the era of imatinib: a retrospective multicentre study. Eur J Haematol 76:9-17. doi:10.1111/j.0902-4441.2005.t01-1-EJH2321.x

11. Kujawski L, Talpaz M (2007) Strategies for overcoming imatinib resistance in chronic myeloid leukemia. Leuk Lymphoma 48:2310-2322. doi:10.1080/10428190701665988

12. Frame D (2006) Chronic myeloid leukemia: standard treatment options. Am J Health Syst Pharm 63:S10-S14. doi:10.2146/ ajhp060525

13. Crawley C, Szydlo R, Lalancette M, Bacigalupo A, Lange A, Brune M, Juliusson G, Nagler A, Gratwohl A, Passweg J, Komarnicki M, Vitek A, Mayer J, Zander A, Sierra J, Rambaldi A, Ringden O, Niederwieser D, Apperley JF (2005) Outcomes of reduced-intensity transplantation for chronic myeloid leukemia: an analysis of prognostic factors from the Chronic Leukemia Working Party of the EBMT. Blood 106:2969-2976. doi:10.1182/blood2004-09-3544

14. Kebriaei P, Saliba RM, Ma C, Ippoliti C, Couriel DR, de LM, Giralt S, Qazilbash MH, Gajewski JL, Ha CS, Champlin RE, Khouri IF (2006) Allogeneic hematopoietic stem cell transplantation after rituximab-containing myeloablative preparative regimen for acute lymphoblastic leukemia. Bone Marrow Transplant 38:203-209. doi:10.1038/sj.bmt.1705425

15. Slavin S, Nagler A, Naparstek E, Kapelushnik Y, Aker M, Cividalli G, Varadi G, Kirschbaum M, Ackerstein A, Samuel S, Amar A, Brautbar C, Ben-Tal O, Eldor A, Or R (1998) Nonmyeloablative stem cell transplantation and cell therapy as an alternative to conventional bone marrow transplantation with lethal cytoreduction for the treatment of malignant and nonmalignant hematologic diseases. Blood 91:756-763

16. McSweeney PA, Niederwieser D, Shizuru JA, Sandmaier BM, Molina AJ, Maloney DG, Chauncey TR, Gooley TA, Hegenbart U, Nash RA, Radich J, Wagner JL, Minor S, Appelbaum FR, Bensinger WI, Bryant E, Flowers ME, Georges GE, Grumet FC, Kiem HP, Torok-Storb B, Yu C, Blume KG, Storb RF (2001) Hematopoietic cell transplantation in older patients with hematologic malignancies: replacing high-dose cytotoxic therapy with graft-versus-tumor effects. Blood 97:3390-3400. doi:10.1182/ blood.V97.11.3390

17. Ottinger HD, Albert E, Arnold R, Beelen DW, Blasczyk R, Bunjes D, Burdach S, Ebell W, Ehninger G, Einsele H, Enczmann J, Fauser A, Friedrich W, Finke J, Gobel U, Goldmann SF, Gramatzki M, Helbig W, Kanz L, Klingebiel T, Kolb HJ, Kuhnl P, Loliger C, Muller CR, Grosse-Wilde H (1997) German consensus on immunogenetic donor search for transplantation of allogeneic bone marrow and peripheral blood stem cells. Bone Marrow Transplant 20:101-105. doi:10.1038/sj.bmt.1700851

18. Ottinger HD, Muller CR, Goldmann SF, Albert E, Arnold R, Beelen DW, Blasczyk R, Bunjes D, Casper J, Ebell W, Ehninger G, Eiermann T, Einsele H, Fauser A, Ferencik S, Finke J, Hertenstein B, Heyll A, Klingebiel T, Knipper A, Kremens B, Kolb HJ, Kolbe K, Lenartz E, Lindemann M, Muller CA, Mytilineos J, Niederwieser D, Runde V, Sayer H, Schaefer UW, Schmitz N, Schroder S, Schulze-Rath R, Schwerdtfeger R, Siegert W, Thiele B, Zander AR, Grosse-Wilde H (2001) Second German consensus on immunogenetic donor search for allotransplantation of hematopoietic stem cells. Ann Hematol 80:706-714. doi:10.1007/s00277-001-0384-9

19. Gratwohl A, Hermans J, Goldman JM, Arcese W, Carreras E, Devergie A, Frassoni F, Gahrton G, Kolb HJ, Niederwieser D, Ruutu T, Vernant JP, De WT, Apperley J (1998) Risk assessment for patients with chronic myeloid leukaemia before allogeneic blood or marrow transplantation. Chronic Leukemia Working Party of the European Group for Blood and Marrow Transplan- 
tation. Lancet 352:1087-1092. doi:10.1016/S0140-6736(98) 03030-X

20. Gratwohl A, Brand R, Apperley J, Crawley C, Ruutu T, Corradini P, Carreras E, Devergie A, Guglielmi C, Kolb HJ, Niederwieser D (2006) Allogeneic hematopoietic stem cell transplantation for chronic myeloid leukemia in Europe 2006: transplant activity, long-term data and current results. An analysis by the Chronic Leukemia Working Party of the European Group for Blood and Marrow Transplantation (EBMT). Haematologica 91:513-521

21. Remberger M, Ringden O, Blau IW, Ottinger H, Kremens B, Kiehl MG, Aschan J, Beelen DW, Basara N, Kumlien G, Fauser AA, Runde V (2001) No difference in graft-versus-host disease, relapse, and survival comparing peripheral stem cells to bone marrow using unrelated donors. Blood 98:1739-1745. doi:10.1182/blood. V98.6.1739

22. Elmaagacli AH, Basoglu S, Peceny R, Trenschel R, Ottinger H, Lollert A, Runde V, Grosse-Wilde H, Beelen DW, Schaefer UW (2002) Improved disease-free-survival after transplantation of peripheral blood stem cells as compared with bone marrow from HLA-identical unrelated donors in patients with first chronic phase chronic myeloid leukemia. Blood 99:1130-1135

23. Champlin RE, Schmitz N, Horowitz MM, Chapuis B, Chopra R, Cornelissen JJ, Gale RP, Goldman JM, Loberiza FR Jr, Hertenstein B, Klein JP, Montserrat E, Zhang MJ, Ringden O, Tomany SC, Rowlings PA, Van Hoef ME, Gratwohl A (2000) Blood stem cells compared with bone marrow as a source of hematopoietic cells for allogeneic transplantation. IBMTR Histocompatibility and Stem Cell Sources Working Committee and the European Group for Blood and Marrow Transplantation (EBMT). Blood 95:3702-3709

24. McGlave PB, Shu XO, Wen W, Anasetti C, Nademanee A, Champlin R, Antin JH, Kernan NA, King R, Weisdorf DJ (2000) Unrelated donor marrow transplantation for chronic myelogenous leukemia: 9 years' experience of the national marrow donor program. Blood 95:2219-2225

25. Weisdorf DJ, Anasetti C, Antin JH, Kernan NA, Kollman C, Snyder D, Petersdorf E, Nelson G, McGlave P (2002) Allogeneic bone marrow transplantation for chronic myelogenous leukemia: comparative analysis of unrelated versus matched sibling donor transplantation. Blood 99:1971-1977. doi:10.1182/blood.V99. 6.1971

26. Faber E, Koza V, Vitek A, Mayer J, Sedlacek P, Zak P, Zapletalova J, Benesova K, Krejcova H, Steinerova K, Maresova I, Cetkovsky P (2007) Reduced-intensity conditioning for allogeneic stem cell transplantation in patients with chronic myeloid leukemia is associated with better overall survival but inferior disease-free survival when compared with myeloablative conditioning - a retrospective study of the Czech National Hematopoietic Stem Cell Transplantation Registry. Neoplasma $54: 443-446$
27. Chen MH, Chiou TJ, Lin PC, Gau JP, Hsu HC, Hsiao LT, Liu JH, Chen PM (2007) Comparison of myeloablative and nonmyeloablative hematopoietic stem cell transplantation for treatment of chronic myeloid leukemia. Int $\mathrm{J}$ Hematol 86:275-281. doi:10.1007/BF03006933

28. Kojima R, Kami M, Kanda Y, Kusumi E, Kishi Y, Tanaka Y, Yoshioka S, Morishima S, Fujisawa S, Mori SI, Kasai M, Hatanaka K, Tajima K, Kasai M, Mitani K, Ichinohe T, Hirai H, Taniguchi S, Sakamaki H, Harada M, Takaue Y (2005) Comparison between reduced intensity and conventional myeloablative allogeneic stem-cell transplantation in patients with hematologic malignancies aged between 50 and 59 years. Bone Marrow Transplant 36:667-674. doi:10.1038/sj.bmt.1705122

29. Kantarjian HM, O'Brien S, Cortes JE, Giralt SA, Rios MB, Shan J, Giles FJ, Thomas DA, Faderl S, de LM, Garcia-Manero G, Champlin R, Arlinghaus R, Talpaz M (2002) Imatinib mesylate therapy for relapse after allogeneic stem cell transplantation for chronic myelogenous leukemia. Blood 100:1590-1595

30. Millot F, Guilhot J, Nelken B, Leblanc T, De Bont ES, Bekassy AN, Gadner H, Sufliarska S, Stary J, Gschaidmeier H, Guilhot F, Suttorp M (2006) Imatinib mesylate is effective in children with chronic myelogenous leukemia in late chronic and advanced phase and in relapse after stem cell transplantation. Leukemia 20:187-192. doi:10.1038/sj.leu.2404051

31. Olavarria E, Siddique S, Griffiths MJ, Avery S, Byrne JL, Piper KP, Lennard AL, Pallan L, Arrazi JM, Perz JB, O'Shea D, Goldman JM, Apperley JF, Craddock CF (2007) Posttransplantation imatinib as a strategy to postpone the requirement for immunotherapy in patients undergoing reduced-intensity allografts for chronic myeloid leukemia. Blood 110:4614-4617. doi:10.1182/blood-2007-04-082990

32. DeAngelo DJ, Hochberg EP, Alyea EP, Longtine J, Lee S, Galinsky I, Parekkedon B, Ritz J, Antin JH, Stone RM, Soiffer RJ (2004) Extended follow-up of patients treated with imatinib mesylate (gleevec) for chronic myelogenous leukemia relapse after allogeneic transplantation: durable cytogenetic remission and conversion to complete donor chimerism without graft-versus-host disease. Clin Cancer Res 10:5065-5071. doi:10.1158/1078-0432. CCR-03-0580

33. Atallah E, Kantarjian H, De Lima M, Borthakur G, Wierda W, Champlin R, Cortes J (2006) The role of dasatinib in patients with Philadelphia $(\mathrm{Ph})$ positive acute lymphocytic leukemia (ALL) and chronic myeloid leukemia (CML) relapsing after stem cell transplantation (SCT). Blood $\cdots: 108$. abstract 4520.

34. Jabbour E, Cortes J, Kantarjian HM, Giralt S, Jones D, Jones R, Giles F, Andersson BS, Champlin R, de Lima M (2006) Allogeneic stem cell transplantation for patients with chronic myeloid leukemia and acute lymphocytic leukemia after Bcr-Abl kinase mutation-related imatinib failure. Blood 108:1421-1423. doi:10.1182/blood-2006-02-001933 